\title{
UPAYA SEKOLAH DALAM MENUMBUHKAN BUDAYA LITERASI SAINS DI SD NEGERI DEMANGAN YOGYAKARTA
}

\author{
Hayaturraiyan $^{1}$ \\ STAI Darul Kamal NW Kembang Kerang NTB \\ hayat.raiyan@gmail.com
}

\begin{abstract}
Abstrak
Literasi sains merupakan hal fundamental untuk dimiliki oleh siswa sebagai bekal dalam menghadapi perkembangan sains dan teknologi yang semakin canggih. Seyogyanya para lembaga pendidik dan tenaga kependidikan dapat menumbuhkan budaya literasi sains kepada siswa sejak usia sekolah dasar. Berdasarkan hal tersebut penelitian ini bertujuan untuk memaparkan upaya sekolah dalam menumbuhkan budaya literasi sains di SD Negeri Demangan Yogyakarta. Penelitian ini menggunakan metode kualitatif jenis studi kasus. Pengumpulan data menggunakan teknik wawancara langsung, observasi, dan dokumentasi. Analisis data menggunakan model Miles dan Huberman. Pemeriksaan keabsahan data dilakukan dengan triangulasi teknik dan sumber. Hasil penelitian ini menunjukkan bahwa, untuk menumbuhkan budaya literasi sains, sekolah melaksanakan kegiatan-kegiatan yang dapat menumbuhkan kemampuan literasi sains siswa seperti: membaca, eksperimen, melestarikan lingkungan, sosialisasi dan simulasi tanggap bencana gempa bumi, dan outdoor study. Agar kegiatan literasi sains berjalan lancar sekolah menyediakan fasilitas seperti: pembangunan gazebo, pembuatan pojok baca, bahan bacaan, lahan untuk penghijauan, alat peraga pembelajaran IPA.
\end{abstract}

\section{PENDAHULUAN}

Terpenuhinya literasi memungkinkan untuk dapat mengakses berbagai macam pengetahuan, karena literasi tidak hanya sekedar mampu membaca dan menulis saja, namun literasi juga mampu mengakses, memahami, dan menggunakan sesuatu secara cerdas melalui berbagai aktivitas seperti: membaca, melihat, menyimak, menulis, dan berbicara, oleh karena itu literasi penting untuk dibudayakan oleh semua masyarakat pada umumnya, peserta didik pada khususnya. Namun sayangnya tingkat literasi masyarakat Indonesia masih rendah. Hal tersebut terlihat dari hasil studi Programme for Internasional Student Assessment (PISA) 2018 yang dirilis oleh United Nations Educational, Scientific and Cultural Organization (OECD) menunjukkan bahwa kemampuan siswa Indonesia dalam membaca, meraih skor rata-rata yakni 371, dengan rata-rata skor OECD yakni 487. Kemudian skor rata-rata untuk matematika mencapai 379 dengan skor rata-rata OECD 487. Selanjutnya untuk sains, skor rata-rata siswa Indonesia mencapai 389

\footnotetext{
${ }^{1}$ Dosen STAI Darul Kamal NW Kembang Kerang NTB
} 
dengan skor rata-rata OECD yakni 489.2 Berdasarkan hasil studi PISA tersebut dapat diketahui bahwa keadaan literasi di Indonesia masih menduduki posisi rendah.

Literasi sains merupakan bagian dari gerakan literasi sekolah (GLS) yang dicanangkan oleh Menteri Kebudayaan dan Pendidikan sejak tahun 2015. Tidak semua sekolah menjalankan gerakan literasi sekolah karena untuk menjalankan program tersebut ada beberapa pasilitas yang perlu dipersiapkan oleh sekolah. SD Negeri Demangan Yogyakarta merupakan salah satu sekolah yang dipercaya untuk menjalankan GLS yang di dalamnya termasuk literasi sains sejak tahun 2017. Literasi sains berasal dari gabungan dua kata latin yaitu literatus artinya ditandai dengan pengetahuan huruf atau melek huruf, dan scientia yang artinya memiliki pengetahuan. Istilah literasi sains pertama kali dikemukakan oleh Paul de Hart Hurth, seorang ahli pendidikan sains yang terkenal, pada tahun 1958. Ia menggunakan istilah literasi sains untuk menjelaskan pemahaman tentang sains dan penerapannya dalam pengalaman sosial. Hal tersebut menunjukkan bahwa literasi sains bukanlah hal yang baru ada dan diterapkan, sedangkan dari pengertian tersebut dapat dipahami bahwa istilah literasi sains penerapannya tidak hanya terbatas pada penomena alam pelajaran IPA saja, akan tetapi penomena sosialpun pelajaran IPS jika dikaji, dianalisis dan dipahami secara mendalam, juga merupakan kegiatan literasi sains.

Kemajuan sains dan teknologi tidak bisa dihindari dalam kehidupan sosial, oleh karena itu jika ingin melihat kemajuan peradaban manusia, maka lihat kemajuan sains dan teknologinya, karena kemajuan sains dan teknogi akan berjalan sesuai dengan kemajuan peradaban ilmu pengetahuan. Kemajuan sains dan teknologi akan menciptakan inovasi-inovasi baru yang memberikan manfaat bagi kehidupan manusia sehingga segala sesuatu dapat dikerjakan dengan mudah dan cepat. Contohnya teknologi yang ada sekitar kita dan hampir setiap orang menggunakannya yaitu hanpone. Hanpone memiliki manfaatnya sangat banyak dalam kehidupan manusia seperti, mudah menghubungi kerabat yang berada di tempat jauh, mudah mengakses informasi dengan cepat. Namun, dibalik manfaat tersebut juga dapat mendatangkan kemudaratan seperti: kurangnya kepedulian manusia terhadap lingkungan sekitar, karena fokus terhadap hanpone yang dimilikinya, menjadi ketergantungan, mendapat informasi yang belum tentu kebenarannya. Untuk menghindari hal tersebut diperlukan kecerdasan ilmu pengetahuan agar dapat memanfaatkan teknologi dengan baik dan bijak.

Berdasarkan dampak dari perkembangan sains dan teknologi, maka seyogyanya para lembaga pendidik dan tenaga kependidikan dapat membekali peserta didik sejak usia sekolah dasar, agar cerdas dalam memanfaatkan teknologi, memiliki kemampuan menyelidiki, serta

\footnotetext{
2 Biro Komunikasi dan layanan Masyarakat Kementrian Pendidikan dan Kebudayaan. 2019. Hasil PISA Indonesia 2018: Akses Makin Meluas. Saatnya Tingkatkan Kualitas. https://www.kemdikbud.go.id. Diakses tanggal 18 Desember 2020. Pukul 20.10 WITA.
} 
mengambil keputusan sesuai dengan fakta yang ada melalui budaya literasi sains, karena materi sains di tingkat sekolah dasar mengedepankan kreativitas siswa baik secara pengetahuan teoritik, maupun praktik melalui keterampilan proses sains. Hal tersebut selaras dengan sudut pandang OECD, 2016, mendefinisikan literasi sains sebagai pengetahuan dan kecakapan ilmiah untuk mampu mengidentifikasikan pertanyaan, memperoleh pengetahuan baru, menjelaskan fenomena ilmiah, serta mengambil simpulan berdasar fakta, memahami karakteristk sains, kesadaran bagaimana sains dan teknologi membentuk lingkungan alam, intelektual, dan budaya, serta kemauan untuk terlibat dan peduli terhadap isu-isu yang terkait sains. ${ }^{3}$

Di Indinesia secara eksplisit keterampilan literasi sains diterapkan pada pembelajaran IPA. Sehubungan dengan hal tersebut, maka penguasaan kemampuan literasi sains sudah seharusnya dimulai dalam pembelajaran IPA di sekolah dasar. Pada dasarnya kegiatan pembelajaran IPA tidak hanya berorientasi pada penguasaan konsep dan teori saja, akan tetapi mampu mengaplikasikannya dalam kegiatan kehidupan sehari-hari serta lingkungan sekitar supaya kegiatan pembelajaran IPA lebih bermakna, oleh karena itu, sekolah perlu mengarahkan siswa agar terbiasa melakukan kegiatan-kegiatan yang menambah kemampuan sains siswa.

\section{BUDAYA LITERASI SAINS}

Sebelum membahas literasi sains terlebih dahulu pahami apa yang dimaksud dengan budaya. Dalam Kamus Besar Bahasa Indonesia (KBBI) mengartikan budaya adalah sesuatu yang menjadi kebiasaan dan susah untuk diubah. Sedangkan literasi sains berasal dari gabungan dua kata latin yaitu literatus, artinya ditandai dengan mengetahui huruf atau melek huruf, dan scientia, yang artinya memiliki pengetahuan. Sedangkan sains berasal dari kata science merupakan istilah yang mengacu pada masalah kealaman (nature). ${ }^{4}$ Istilah literasi sains pertama kali dikemukakan oleh Paul de Hart Hurth, ia mengartikan scient literacy merupakan tindakan memahami sains dan mengaplikasikannya bagi kebutuhan masyarakat.

Berdasarkan definisi yang telah dikemukakan di atas dapat dipahami bahwa budaya literasi sains adalah kegiatan yang membiasakan siswa untuk memiliki pengetahuan dan kecakapan ilmiah agar mampu mengidentifikasi pertanyaan, memperoleh pengetahuan baru, menjelaskan fenomena ilmiah, mengambil simpulan berdasar fakta, memahami karakteristik sains, kesadaran bagaimana sains dan teknologi membentuk lingkungan alam, intelektual, dan budaya, serta kemauan untuk terlibat dan peduli terhadap isu-isu yang terkait sains sehingga dapat bermanfaat bagi dirinya, masyarakat dan lingkungan sekitar.

\footnotetext{
${ }^{3}$ Muhammad Randy Fananta, dkk, Materi Pendukung Literasi Sain: Gerakan Letarasi Nasional, (Jakarta: Kementerian Pendidikan dan Kebudayaan, 2017), 5.

${ }^{4}$ Usman Samatowa, Pembelajaran IPA Di Sekolah Dasar, (Jakarta: Indeks, 2011), 19.
} 


\section{Tujuan Budaya Literasi Sains}

Ada lima tujuan dari literasi sains diantaranya: (1) Tumbuhnya kesadarpahaman untuk peduli terhadap lingkungan dan pemeliharaannya. (2) Tumbuhnya budaya berpikir inkuiri (mengamati, selalu bertanya dalam mengidentifikasi masalah, melakukan eksplorasi, dan melakukan penarikan simpulan hingga ke tahap pengambilan keputusan) dalam memecahkan permasalahan sains. (3) Menguatnya kebiasaan berpikir saintifik, seperti selalu ingin tahu (wonderment), berpikir terbuka (open minded), kreatif, memperhatikan keselamatan, dan menjadi penentu keputusan. (4) Tumbuhnya kecakapan untuk menghubungkan konsep yang dipelajari di sekolah dengan konteks fenomena alam sekitarnya. (5) Menguatnya kolaborasi dalam perancangan visi dan misi terkait dengan literasi sains yang melibatkan warga sekolah dan pihakpihak yang berkepentingan. ${ }^{5}$

\section{Indikator Literasi Sains Basis Budaya Sekolah}

Indikator budaya literasi sains yang telah dirumuskan oleh tim penyusun materi pendukung literasi sains sebagai berikut: (1) Jumlah dan variasi bahan bacaan literasi sains. (2) Frekuensi peminjaman bahan bacaan literasi sains. (3) Jumlah kegiatan literasi sains di sekolah. (4) Akses situs daring yang berhubungan dengan literasi sains. (5) Jumlah kegiatan bulan literasi sains. (6) Alokasi dana untuk literasi sains. (7) Adanya tim literasi sekolah. (8) Adanya kebijakan sekolah mengenai literasi sains. (9) Jumlah penyajian informasi literasi sains dalam berbagai bentuk. ${ }^{6}$

\section{METODE PENELITIAN}

Penelitian ini menggunakan pendekatan metode kualitatif. Dari segi lokasi tergolong dalam penelitian lapangan (penelitian kancah), dengan jenis kualitatif studi kasus karena mengkaji peristiwa yang sedang terjadi yaitu, upaya sekolah menumbuhkan budaya literasi sains di SD Negeri Demangan Yogyakarta. Yang menjadi subjek dalam penelitian ini yaitu, kepala sekolah, guru, siswa kelas empat dan lima. Instrumen pengumpulan data berupa pedoman wawancara, lembar pengamatan, daftar dokumentasi peralatan pembelajaran sains, daftar fasilitas pendukung kegiatan literasi sains, dan nama-nama tanaman sebagai kegiatan penghijauan. Teknik pengumplan data menggunakan wawancara langsung, observasi non-partisipan, dan dokumentasi. Analisis data menggunakan model Miles dan Huberman dengan tahapan reduksi data, kemudian menyajikan data, dan diakhiri dengan menarik kesimpulan. Pemeriksaan

\footnotetext{
${ }^{5}$ Gufran Ali Ibrahim, Peta Jalan Gerakan Literasi Nasional, (Jakarta: Kementerian Pendidikan dan Kebudayaan, 2017), 15.

${ }^{6}$ Muhammad Randy Fananta, dkk, Materi Pendukung...,6.
} 
keabsahan data dilakukan dengan triangulasi teknik dan sumber, dengan mengecek temuan dari hasil teknik wawancara, observasi, dan dokumentasi, serta mengecek temuan berdasarkan sumber utama penelitian.

\section{HASIL}

Sekolah SD Negeri demangan Yogyakarta memberi ruang serta mengupayakan agar literasi sains dapat tumbuh dan menjadi budaya bagi siswa. Adapun upaya yang dilakukan oleh sekolah di antaranya: mengadakan kegiatan membaca, mengadakan kegiatan eksperimen, mengadakan kegiatan pelestarian lingkungan, mengadakan kegiatan tanggap bencana gempa bumi, mengadakan kegiatan outdoor study, serta menyiapkan fasilitas yang mendukung kegiatan literasi sains.

\section{Kegiatan Membaca}

Sejak dilaksanakannya program gerakan literasi sekolah, guru mengupayakan agar siswa lebih giat membaca. Kegiatan membaca merupakan suatu aktivitas yang sangat penting bagi masyarakat, khususnya para pelaku pendidikan. Melalui kegiatan membaca seseorang bisa memiliki wawasan yang luas, begitu juga dengan seseorang yang ingin memiliki kemampuan literasi sains, maka harus ditanamkan dalam dirinya minat dan kemampuan membaca yang baik dan kuat. Kegiatan membaca tidak hanya dilaksanakan pada saat proses pembelajaran berlangsung, akan tetapi juga diluar proses pembelajaran seperti: 15 menit sebelum pembelajaran dimulai siswa diminta untuk membaca buku bacaan apa saja yang dimiliki. Selain itu, saat jam istirahat belajar siswa juga disarankan agar berkunjung ke perpustakaan untuk membaca ataupun berdiskusi. Karena di perpustakan banyak jenis buku tersedia yang dapat menambah wawasan siswa. Untuk menarik minta baca siswa buku-buku sains yang disediakan tidak hanya buku pelajaran saja, tetapi buku non-pelajaran juga seperti komik, novel, majalah, dan buku ensklovedia.

Untuk menumbuhkan minat baca siswa, sekolah juga bekerja sama dengan perpustakaan kota yang setiap dua minggu sekalai datang berkunjung ke sekolah membawa berbagai jenis buku bacaan menggunakan armada, yang disebut dengan perpustakaan keliling. Kegiatan membaca merupakan kegiatan literasi sains, karena dengan kegiatan membaca siswa dapat melatih ingatannya serta ketelitiannya dalam memahami bacaan tersebut, selain itu dengan minat baca yang kuat, siswa akan terbiasa dan mampu untuk mencari serta menyelidiki kebenaran informasi sesuai dengan fakta. 


\section{Kegiatan Eksperimen}

Kegiatan eksperimen dilaksanakan saat proses pembelajaran IPA. Agar siswa dapat memperoleh pengetahuan dan pemahaman secara langsung melalui peroses pembelajaran IPA, maka guru menggunakan metode eksperimen, melalui metode eksperimen siswa dapat melakukan percobaan, mengamati, meneliti dan mengambil kesimpulan sesuai dengan hasil percobaannya. Oleh karena itu kegiatan eksperimen mampu menumbuhkan literasi sains, karena melalui kegiatan eksperimen siswa tidak hanya mengerti konsep semata, melainkan dapat mempraktikkan konsep yang di pelajari dalam kehidupan sehari-hari. Melalui kegiatan eksperimen, ingatan siswa tentang materi yang dipelajari akan bertahan lebih lama karena siswa mengalami, melakukan, mengikuti proses, mengamati suatu objek, menganalisis, membuktikan dan menarik kesimpulan sendiri tentang kegiatan eksperimen tersebut. Saat kegiatan eksperimen berlangsung guru bertugas mengawasi dan membimbing siswa agar tidak terjadi kesalahan dan kekeliruan dalam melakukan eksperimen. Siswa dibagi menjadi berkelompok sehingga terjadi intraksi sosial dan kerjasama dalam melasanakan kegiatan eksperimen.

\section{Kegiatan Pelestarian Lingkungan}

Pelestarian lingkungan dapat dilakukan dengan menjaga kebersihan dan melakukan penghijauan. Lingkungan yang bersih dan indah, rapi akan membuat penghuninya nyaman dan sehat. Menyadari hal tersebut guru mengajak siswa agar bersama-sama menjaga kebersihan dengan membuat jadwal tugas bersihan, menyediakan tiga tempat sampah dengan warna yang berbeda yaitu, warna hijau untuk sampah organik, warna kuning untuk sampah anorganik dan warna merah untuk sampah bahan beracun berbahaya. Memajang poster-poster kebersihan lingkungan.

Sekolah melaksanakan kegiatan penghijauan yang dimulai dari lingkungan sekolah yang dilakukan oleh warga sekolah. Dalam kegiatan penghijauan ini, guru membagi siswa menjadi berkelompok setiap kelompok memiliki tanaman untuk dijaga dan dirawat. Adapun jenis tanaman yang ditanam diantaranya: tanaman hias palem, bunga mawar, bunga kamboja, bunga melati, bunga aster, bunga kertas, tanaman jahe, kunyit, laos, pepaya, dan seledri. Kegiatan pelestarian lingkungan dapat dijadikan untuk menumbuhkan budaya literasi sains karena siswa akan memeliki rasa tanggung jawab dan kepedulian terhadap lingkungan, sehingga membuat lingkungan menjadi indah dan asri. 


\section{Kegiatan Tanggap Bencana Gempa Bumi}

Bencana gempa bumi terjadi secara tiba-tiba tanpa bisa diprediksi oleh manusia maupun dikaji secara ilmiah. Bencana gempa bumi bisa memakan korban banyak jika tidak adanya pengetahuan tentang kesiapsiagaan bencana gempa bumi, apalagi di sekolah, siswa jauh dari orang tua, apabila gempa bumi terjadi ketakutan serta kepanikan siswa akan lebih tinggi sehingga menyebabkan terjadinya korban jiwa. Menyadari hal tersebut, sekolah bekerjasama dengan Disdikpora Kota Yogyakarta untuk memberikan sosialisasi dan simulasi mitigasi bencana gempa bumi bagi guru dan siswa. Kegiatan tanggap bencana gempa bumi dipimpin oleh Babinsa Koramil. Dalam kegiatan ini siswa diberi penjelasan bagaimana cara melindungi diri jika terjadi gempa bumi. Selain itu guru dan siswa melakukan simulasi gempa bumi, ketika gempa bumi terjadi, siswa segera mencari tempat yang bisa melindunginya dari benda atau bangunan yang berpotensi roboh, seperti berlindung di kolong meja sambil menunggu bantuan dari guru, setelah ada bantuan siswa dengan tertib keluar dari kelas dengan menaruh tas diatas kepala dan mencari tempat yang lebih aman dibawah pengawasan guru. Sementara guru bertugas membunyikan sirine, memriksa, mengfakuasi siswa yang terluka. Guru memakai helm untuk melindungi kepalanya dan membawa tandu untuk membawa siswa yang menjadi korban.

Kegiatan tanggap bencana dapat dikatakan kegiatan literasi sains karena dapat menambah pengetahuan siswa tentang bagaimana menyelamatkan diri apabila terjadi bencana alam secara tiba-tiba. Kepekaan siswa terhadap bencana alam merupakan kemampuan literasi sains, karena Warga Negara harus memiliki kepekaan terhadap bencana alam dalam konteks personal, lokal dan global.

\section{Outdoor Study}

Belajar dilingkungan sekolah secara terus menerus akan menimbulkan rasa jenuh yang mengakibatkan siswa kurang semagat belajar. Untuk menghindari hal tersebut, sekolah mengadakan kegiatan pembelajaran di luar kelas yang disebut dengan kegiatan outdoor study. Melalui kegiatan outdoor study diharapkan dapat menambah minat belajar siswa, karena siswa dapat melakukan kegiatan yang tidak biasa dilakukan di dalam kelas. Kegiatan outdoor study dilaksanakan setiap setiap bulan dengan kelas yang berbeda-beda. Adapun tempat-tempat yang sering dikunjungi sebagai tempat outdoor study seperti: kebun binatang gembira loka di Rejowinangun, taman pintar di ngupasan, hutan pinus di mangunan, dan musium merapi di dusun banteng. Saat kegiatan outdoor study guru membuat siswa menjadi beberapa kelompok dan menugaskan siswa untuk mengamati alam sekitar dan mengambil pelajaran dari alam tersebut. Berdasarkan lokasi yang dituju, serta kegiatan yang dilakukan, dapat dikatakan melalui kegiatan outdoor study siswa 
dapat belajar langsung dengan alam sehingga siswa mendapat sumber pengetahuan langsung dari alam.

Kegiatan outdoor study dapat dijadikan sebagai kegiatan literasi sains, karena melalui kegiatan outdoor study, siswa dapat belajar dan berinteraksi langsung dengan alam sekitar, dimana alam dapat dijadikan sumber belajar yang dapat dieksplorasi semaksimal mungkin oleh siswa sehingga kecerdasan naturalistiknya bertambah.

\section{Penyediaan Fasilitas Kegiatan Literasi Sains}

Kegiatan-kegiatan yang mendukung budaya literasi sains yang telah dipaparkan tidak akan pernah bejalan jika tidak dilengkapi oleh fasilitas yang memadai. Oleh karena itu, sekolah menyiapkan dan terus melengkapi fasilitas yang digunakan dalam kegiatan-kegitan yang medukung budaya literasi. Adapun fasilitas yang disesiakan di antaranya: (1) Pembangunan gazebo. Gazebo yang dijadikan sebagai tempat baca baru dibangun dua buah. Posisinya tidak jauh dari gerbang sekolah. (2) Pembuatan pojok. Pojok baca yang dibuat sebanyak lima buah, dan diposisikan di depan kelas siswa, hal ini bertujuan jika waktu jam istirahat tiba, siswa dapat membaca buku di halaman kelasnya tanpa berada di dalam kelas terus. Untuk menjaga keutuhan buku, buku yang disediakan di pojok baca tidak banyak, oleh karena itu jika siswa ingin membaca buku-buku yang lain, siswa dibolehkan untuk mengambil buku di perpustakaan dan dibaca do pojok baca setelah itu mengembalikannya kembali ke perpustakaan. (3) Menyediakan bahan bacaan yang berkaitan dengan sains untuk mendukung literasi sains. Adapun bahan bacaan seperti buku fiksi, buku non-fiksi, majalah, koran, kamus, dan ensklopedia. (4) Menyediakan lahan untuk penghijauan. Lahan yang disediakan sebagai tempat tanaman obat-obatan serta sayur-sayuran seluas $6 \times 7 \mathrm{~m}$, selain itu taman-taman di depan kelas juga dimanfaatkan untuk tanaman-tanaman hias seperti bunga sehingga menambah keindahan pemandangan di skolah. (5) Menyediakan alat kebersihan seperti tempat sampah, sapu lidi, sapu, kmoci, lap, ember, dan skop sampah. (6) Menyediakan alat peraga untuk mendukung pembelajaran IPA seperti: cermin cekung, cermin cembung, cermin datar, lensa cekung, lensa cembung, lensa datar, model kerangka manusia, model tubuh manusia, kaca pembesar, magnet batang, poster IPA Metamorphosis, dan poster IPA metamorphosis, torso manusia. Alat-alat tersebut banyak yang rusak seperti kerangka manusia yang tidak bisa dipindah ke kelas jika ingin menggunakaanya dan belum diperbaiki, hal ini dikeranakan belum ada guru yang ditugaskan untuk mengurus alat peraga tersebut. 


\section{SIMPULAN DAN SARAN}

Berdasarkan pemaparan hasil penelitian di atas dapat disimpulkan budaya literasi sains merupakan kegiatan membiasakan siswa agar memiliki pengetahuan dan kecakapan ilmiah, mampu mengidentifikasikan isu-isu di masyarakat, teliti dalam menyelidiki, mampu membuktikan, serta dapat mengambil simpulan berdasar fakta. Untuk mencapai hal tersebut sekolah mengupayakan agar siswa mendapat melakukan pembelajaran langsung dengan melakukan kegiatan-kegiatan yang dapan menambah pengetahuan literasi sains siswa seperti: kegiatan membaca, kegiatan eksperimen, kegiatan pelestarian lingkungan, kegiatan tanggap bencana gempa bumi, dan kegiatan aoutdoor study. Agar kegiatan literasidapat berjalan dengan baik sekolah menyiapkan dan melengkapi fasilitas yang mendukung kegiatan literasi sains.

Adapun saran yang ingin disampaikan kepada sekolah SD Negeri Demangan Yogyakarta yang telah mulai menumbuhkan budaya literasi sains untuk menambah kegiatan-kegiatan yang lebih berpariasi dan dapat meningkatkan kemampuan literasi siswa, serta melengkapi sarana dan prasarana kegiatan literasi sains.

\section{Daftar Pustaka}

Ali, Gufran Ibrahim. (2017). Peta Jalan Gerakan Literasi Nasional. Jakarta: Kementerian Pendidikan dan Kebudayaan.

Biro Komunikasi dan layanan Masyarakat Kementrian Pendidikan dan Kebudayaan. (2019). Hasil PISA Indonesia 2018: Akses Makin Meluas. Saatnya Tingkatkan Kualitas. https://www.kemdikbud.go.id. Diakses tanggal 18 Desember 2020. Pukul 20.10 WITA

Depdikbud. (2005). Kamus Besar Bahasa Indonesia. Jakarta: Balai Pustaka.

Randy, Muhammad Fananta, dkk, (2017). Materi Pendukung Literasi Sain: Gerakan Letarasi Nasional. Jakarta: Kementerian Pendidikan dan Kebudayaan.

Samatowa, Usman. (2011). Pembelajaran IPA di Sekolah Dasar. Jakarta: Indeks.

Soewandi, Slamet. (2008). Persepektif Pembelajaran Berbagai Bidang Studi. Yogyakarta: Universitas Sanata Dharma.

Toharudin, Uus, dkk. (2011). Membangun Literasi Sains Peserta Didik. Bandung: Humaniora. 